\title{
Codeswitching and emotional alignment: Talking about abuse in domestic migrant-worker returnee narratives
}

\author{
H A N S J L A D E G A R D \\ The Hong Kong Polytechnic University
}

\section{A B S T R A C T}

Early research on bilingualism and emotion suggests that bilingual speakers' L1 may be preferred for emotional expression whereas L2 may be used for emotional detachment. The evidence comes primarily from surveys, interviews, and laboratory studies. Studies of bilingual codeswitching (CS) and emotion tend to focus on perception and recollection of experience rather than actual language data. This article uses data from domestic migrant-worker returnee narratives to explore the use of CS in storytelling. Domestic-worker returnees in Indonesia participated in sharing sessions in which they talked about the trauma they experienced while they worked overseas as domestic helpers. CS was widely used and, through a discourse analysis of selected excerpts, the article shows that CS is used for addressee specification and emotional alignment. The article concludes by considering how researchers may use the trauma narratives of repressed groups for social activism. (Codeswitching and emotion, domestic migrant workers, trauma narratives, Indonesia)*

\section{N T R O D U C T I O N}

Being bilingual is not just about speaking and writing in two languages, it is also about thinking and feeling in two languages (Javier 2007). Monolingual children learn to communicate their emotional needs in their mother tongue, and this includes language- and culture-specific norms for communicating emotion appropriately. However, if the child attends a school where a different language (L2) is spoken, s/he might initially have difficulties expressing emotional experiences in L2 because s/he is not socialised into the norms of context-appropriate L2 emotional expression. This is why most people who learn their L2 later in life find it easier to swear in their L2 and to use L2 to talk about sex or other taboos (Dewaele 2016). Thus, some studies have found that L1 is the preferred language for emotional expression (Harris, Gleason, \& Aycicegi 2006), whereas L2 is more likely to be used for emotional detachment (Bond \& Lai 1986). By contrast, a bi- or multilingual child who has become intimately familiar with two or more languages through his/her primary socialisation is usually aware of a wider array of means to both express and decode emotion (Dewaele 2010), each of them 
aligned with language-specific sociocultural norms. Bi- and multilinguals thus create multilayered selves through which they experience the world, including the expression and interpretation of emotion (Panayiotou 2004).

Bilingual speakers' actual language behaviour with other bilinguals is usually characterised by frequent use of codeswitching (CS) (Gardner-Chloros 2009). They experience that 'each language makes the other relative' (Hoffman 1989:273), and CS is therefore a means through which they can pick the expression that most adequately represents their emotional state. It has been argued that some languages do not condone explicit expression of negative emotion, and the bilingual speaker would therefore draw on the other code in order to express anger (Dewaele 2010). Thus, bilinguals draw on dual sources for emotional expression, and they do it because of the nonequivalence between the concepts available to them in their two languages (Wierzbicka 1997). In the context of psychotherapy, research has found that bilinguals can utilise CS and draw on their two codes as a means to deal with difficult emotional issues (Tehrani \& Vaughan 2009). Because L2 learning usually happens in a formal classroom context, it arguably does not involve a person's emotional life as much as his/her L1 (ThassThienemann 1973). Therefore, strong feelings and repressed emotions are believed to be best expressed in the patient's L1, and s/he would ideally 'be able to utilize language-switching as a way to move closer to or gain distance from emotional conflict' (Martinovic \& Altarriba 2013:302).

An important but largely neglected issue in the research on language and emotion is that the evidence comes mainly from surveys, laboratory studies, and studies of autobiographical memory. Studies of bilingual CS and emotion tend to focus on perception and recollection of experience, not actual linguistic behaviour (Ferreira 2017 is a rare exception). This article does not question the importance and validity of existing research, but it argues that a study of people's actual language behaviour might allow us to study whether there is linguistic evidence in favour of the assumption that a switch to L2 might be motivated by the need to create emotional distance to the subject that is being discussed.

The research that is reported in this article is part of on-going study of the life stories of Filipina and Indonesian domestic migrant workers (DMWs). The first phase of the project looked at the women's diasporic stories as they were recorded once a week over a four-year period at a church shelter in Hong Kong (Ladegaard 2017). The second part of the project, which has provided data for this article, looks at DMWs' coming-home narratives. It explores their experiences of migration and how they reconnect with children, spouses, and friends they have been separated from for years. Coming-home narratives were recorded in sharing sessions in nineteen villages in East and Central Java including a total of sixty-seven migrantworker returnees. During the sharing, it was noticeable that CS occurred frequently, and it was deployed during the narration of particularly difficult experiences. The aim of this article is to explore how and when CS was used, and try to explain 
the rationale behind it. This is accomplished through a discourse analysis of selected excerpts where CS plays an important role.

\section{T H E S T U D Y}

\section{Background}

Official policies on labour migration fail to recognise the pain and suffering experienced by migrant workers. The suffering is caused by long-term separation (Parreñas 2005), and by the exploitation and abuse experienced by shockingly large numbers of migrant workers. In most of the countries that receive migrant workers, particularly in the Middle East, migrant labour laws are notably absent; in other receiving countries (such as Hong Kong), migrant labour laws exist, but because there is no mechanism in place to ensure they are being enforced, employers may get away with blatant labour-law violations, such as underpayment, cancellation of statutory holidays, insufficient food, and no proper accommodation. Even cases of verbal abuse and physical or sexual assault often go unnoticed because they are difficult to prove (Ladegaard 2017).

The majority of migrant workers are women. They work on two-year contracts as domestic helpers, primarily in Middle Eastern countries like Saudi Arabia, United Arab Emirates (UAE), and Kuwait, or in Asian countries like Malaysia, Singapore, Hong Kong, and Taiwan. The Philippines is the greatest exporter of migrant labour in the global economy with an estimated 9.5 million migrant workers working overseas. Indonesian migrant workers comprise around 6.5 million, but the figure is sharply increasing with around 400,000 new migrant workers leaving Indonesia every year; more than $60 \%$ of them are women. More than half of these new migrants go to just two countries: Saudi Arabia and Malaysia. They are the preferred destinations because the women assume that if they go to work for their Muslim brothers and sisters, they will be treated well. Another benefit that applies to Saudi Arabia is that they may be allowed to do the Holy Pilgrimage to Mecca while they are there. However, rather than a much anticipated religious journey, and a brotherly/sisterly relationship with their employers, many DMWs find that they are being exploited and abused.

\section{Data collection}

During the first phase of the project, more than 300 DMW narratives were collected at a church shelter in Hong Kong. DMWs' return to their home country was often brought up as a theme in sharing sessions at the shelter, so the turn to returnee narratives developed naturally out of this work. The fieldtrips to Indonesia and the Philippines served dual purposes: (i) to collect data for the research project, and (ii) to review whether the Home Country Integration programme provided by a Hong Kong NGO had any positive impact in terms of sustaining DMWs financially upon their return to Indonesia. A similar fieldtrip was organised in the Philippines, 
but because sharing sessions were conducted in English, and there was little CS involved, the data is not included in this article.

The fieldtrips lasted four weeks and I travelled with a driver and an interpreter from village to village to visit former migrant workers. They had been approached before my arrival by local NGOs to ask if they wanted to meet with me and share their experiences of coming home. Some sharing sessions were held in the migrant workers' homes; others were held outside at a central location in the village. Most of the sharing sessions included four to six returnees, but some women preferred to talk to me and/or the interpreter alone so we would record their stories one-to-one.

Each sharing session lasted one to two hours and only three general questions were asked: (i) What was it like to be a migrant worker?, (ii) What was it like to come home?, and (iii) What are you thinking about the future? Follow-up questions would occasionally be asked but the idea was to let the women talk about issues that were important to them. Some women spent most of the time on question (i); their experiences had been horrifying and this might have been the first opportunity given to them to talk about them. A total of 107 DMW returnees participated in the sharing sessions: sixty-seven in East and Central Java in Indonesia, thirtyfour in Bohol in the Philippines, and six women participated in a predeparture sharing session shortly before they were deported from Hong Kong. Each sharing session was transcribed and, for the Indonesian data, translated by an Indonesian university graduate who was fluent in English, Bahasa, and Javanese.

\section{Theoretical and methodological frameworks}

The research is informed by several methodological and analytical concepts from anthropology, narratology, and sociolinguistics. It uses the concept of sharing sessions where the main idea is the sharing of life stories. There was no interview guide or predefined research questions; rather, the aim was to get the women to tell stories that were important to them. The stories were collected using the ethnography-of-communication approach (Saville-Troike 2003), which argues that researchers need to include as much contextual information as possible in the interpretation of data. Staying with migrant-worker families was invaluable in terms of understanding their life circumstances; the four years I had spent at the shelter in Hong Kong also provided me with essential background information.

Another framework that is important for understanding how the narratives are conceptualised is social constructionism (Burr 2015), a discourse-focused framework, which argues that narratives are situated and dynamic discursive constructions. It posits that when people tell stories, they also present and negotiate their social identities. A social constructionist approach to storytelling would argue that stories are not given but constructed in discourse as mutual accomplishments between narrator, interlocutor(s), and audience. Social constructionism sees storytelling as constitutive of context and the people who narrate as social actors (Augoustinos, Walker, \& Donaghue 2014). Ochs \& Capps (2001) suggest a 
continuum between what they call the 'default narrative' with only one active storyteller at the one end, and a dynamic co-constructed narrative with multiple tellers at the other. They claim that the default narrative, which has been studied the most, is in fact quite rare in natural group conversation. This is confirmed in the returnee narratives where most stories have multiple storytellers.

The stories were analysed using a narrative-analysis approach that combines Toolan's (2001) attention to linguistic detail with a narrative therapy approach (White \& Epston 1990). Toolan (2001) argues that analysts need to pay equal attention to narrative structure and function, and by analysing the linguistic components of narrative, we get information about the narrative itself as well as its narrator(s) and audience. Narrative therapy argues that people live storied lives (White \& Epston 1990), and they should therefore be encouraged to tell their stories to make sense of past experiences because 'our stories do not simply represent or mirror lived events - they constitute us, shaping our lives and our relationships' (Brown \& Augusta-Scott 2007:ix). A key assumption behind narrative therapy is therefore that helping people to reinterpret their life stories may help them change their actual lives.

Storytelling serves at least five key functions: (i) it creates coherence by synthesising personal experiences; (ii) it serves a distancing function by helping the storyteller to distance herself from the immediacy of her experiences by converting them into stories; (iii) it serves a communicative function in that it connects the narrator to her audience; (iv) it helps the narrator evaluate her past experiences, providing a wider perspective and the possibility of reinterpreting past events; and (v) it serves an explorative/therapeutic function (Medved \& Brockmeier 2008).

\section{B I L I N G U A L I S M, C O D E S W I T C H IN G, A N D E M OT I ON}

There is a long tradition in sociolinguistics and psycholinguistics of studying the relationship between language and emotion (see Pavlenko 2005, 2006; Dewaele 2010). Bond \& Lai (1986) argue that it is during children's primary socialisation that they become familiar with the sanctions that are involved in violating social norms, and the feelings of embarrassment that such violations lead to. For most children, this type of implicit learning is associated with their L1, and therefore, they learn to avoid expressions that would cause feelings of shame and embarrassment. Educational settings, where most people learn their L2, tend to be more emotionally neutral, which means that emotional arousal is not associated with L2 vocabulary to the same extent. This means that topics that are off-limits in L1 become more approachable in $\mathrm{L} 2$.

There is plenty of evidence to support this conclusion. Dewaele (2016) reports that for most bilinguals, swearing is significantly easier in L2 than in L1, and Necef (1999) found that Turkish-Danish bilingual adolescents switched spontaneously from Turkish to Danish when discussing topics of a sexual nature. Research has 
also found that bilinguals whose first language does not condone explicit expressions of anger (such as Japanese) find it easier to be angry in their L2 (English). And Dewaele (2016:473) reports on research among multilinguals who say they feel 'significantly less logical, less serious, less emotional and increasingly fake when using their L2, L3 and L4 compared to their L1'. This supports the idea that people's L1 somehow feels more authentic and closer to the heart. Thus, the conclusion is that different languages allow people to perform a variety of selves (Koven 2006), and for some bi/multi-linguals, certain emotional expressions align better with some languages than with others.

When it comes to CS, sociolinguists have argued that bilinguals may use it to mark affective stance. Gumperz (1982:80) proposes a distinction between personalisation and objectivisation: the degree of speaker involvement in, or distance from, a message. Bilinguals may use their L1 to signal intimacy, we-ness, and increased emotional involvement, and use their L2 to signal distance, out-group attitude, and emotional detachment (Pavlenko 2004). Bond \& Lai (1986) studied English-Cantonese bilinguals in an experimental setting in Hong Kong. They found that if interviewees were allowed to codeswitch, they consistently switched to their L2 (English) and spoke more in their L2 when asked to talk about embarrassing topics. The authors conclude that $\mathrm{CS}$ to $\mathrm{L} 2$ may serve a distancing function because it allows the speaker to address topics that would be too upsetting in L1. Marcos (1976a) discusses language use and emotion in psychotherapy and reaches a similar conclusion. He argues that a patient's L2 serves an intellectual function, devoid of emotion, whereas L1 contains emotional content. CS to L2 could therefore lead to a detachment effect, which would allow the patient to talk about particularly troubling events without being overcome with grief (Martinovic \& Altarriba 2013).

However, whether switching to L2 leads to reduced emotionality is still a contentious issue. Some scholars are cautious and argue that the main reason for bilinguals to codeswitch is the nonequivalence between concepts in different languages, not that L1 usage is always more emotional (Pavlenko 2004). And Panayiotou (2004:134) posits that the bilingual self is found and founded in two languages, and which language is more or less emotional depends on context and individual needs. Martinovic \& Altarriba (2013:313) conclude that CS may serve dual purposes: first, 'as a tool to gain a clearer understanding of what an individual is attempting to convey', and second, 'as a distancing mechanism to probe into issues that may be too emotional in one of the bilingual's languages'.

\section{A T A A N A Y S IS}

The first example is from a sharing session in East Java with five DMW returnees. The women worked under gruelling circumstances in Saudi Arabia, Malaysia, and UAE. Sari was particularly hard hit. Prior to the question in line 1, she tells the group that she worked from 5am until midnight seven days a week; she had very 
little food and no rest during the day, and she was constantly being yelled at by her female employer.

(1) Sari, thirty-four years old, four years in Saudi Arabia, four years in UAE. Four more DMWs were in this sharing session. A female interpreter (Int) and a male fieldworker (FW) were in all of the sharing sessions. Bahasa is in bold. ${ }^{1}$

1 FW: has anybody helped you talk about this after you came back?

2 Int: oke waktu//

'okay when//'

3 Sari: //iya (sobs) pernah saya ngomong, tapi kan saya juga

4 susah kadang kalau ngeluarin itu, susah gitu

'//yes (sobs) I've talked but I also sometimes have difficulties

expressing [myself], difficult like that'

5 Int: okay, it's not easy for her to share her story, she's tried but

6 it's kind of not easy (quietly to FW)

7 Sari: the trauma is so deep (sobs)

8 FW: yeah, how many years now?

9 Sari: three years

$10 \mathrm{FW}$ : three years ago okay (1.0) yeah okay, how do you feel now?

11 Sari I think everything is the same, what, what I feel is, until

12 now is the same (sobs)

13 FW: just take your time, right? (6.0) have you thought about this

14 many times or is it the first time? have you talked to $\mathrm{Mr}$ (name)

15 or is it the first time?

16 Sari: no this is not the first time, it's always like this if I raise it,

17 also I cannot, I cannot, right? (1.0) the pain is the same,

18 I go home I'm sick (2.0) I cannot xx (sobs)

19 FW: it's okay

Sari is a woman in great emotional distress as she recollects what happened to her while she worked in UAE. Not only was she worn out from hard labour and too little food and sleep, her female employer falsely accused her of stealing an expensive necklace. She was reported to the police, put in jail, and eventually deported from the country. But the final straw for her is that she overhears her female employer confide in a friend that the necklace disappeared before Sari joined the household; she accused her of stealing it because she wanted her to leave. There was another Indonesian domestic worker in the family, and she sided with the employer and told lies about Sari to get her to leave. It is the sense of betrayal from people who claim to be Muslim sisters that plunged Sari into depression.

She tells her story in Bahasa (the dominant language in most sharing sessions), and in line 3 she breaks down in tears. She cries repeatedly as she remembers what happened to her, and it signifies that she is overwhelmed and experiences a loss of control. Crying is commonly perceived as a sign of helplessness and powerlessness (Vingerhoets, Boelhouwer, van Tilburg, \& van Heck 2001). In one of the few 
studies on adult crying that is based on authentic crying in psychotherapy, Labott (2001:222) argues that factors that accounted for the crying included (i) a significant amount of unexpressed and unfinished emotion from earlier events, (ii) a great deal of stress and upset in the patient's current life situation, (iii) the patient felt safe with the therapist, and (iv) the counselling/storytelling made her access earlier memories and feelings. There is evidence in Sari's story that these factors also apply in her case. She also suffers from unexpressed and unfinished emotion ("everything is the same, what I feel is, until now is the same", lines 11-12); her current situation is as bad as it was ("the pain is the same", line 17); the storytelling makes her access earlier memories (just prior to the lines quoted in (1), she recounts the betrayal she experienced being falsely accused of theft); and finally, the relative ease with which she tells her story shows that she feels safe with the group (see Ladegaard 2014).

The shift to English in line 7 is significant. At this point, Sari is about five minutes into the first part of her narrative, which is about fifteen minutes long, and it is the first time she switches. We could argue that it is caused by the translator's shift to English (lines 5-6) to translate Sari's statement. However, this may not be the main reason because (i) this happened before during Sari's storytelling and did not lead her to switch, and (ii) the translator's voice is barely audible. It is also possible that she is appealing to the fieldworker for sympathy. Gardner-Chloros (2009) points out that CS is frequently used as a means to accommodate to the interlocutor's linguistic preference, that is, a form of addressee specification (Gumperz 1982). However, this might also have happened earlier in the storytelling where Sari's story was translated, but it did not. The content of Sari's utterance is arguably important: 'the trauma is so deep' (line 7) followed by intense crying. This comment is like a climax; she finally verbalises what she has hinted at earlier: that she is traumatised.

This is even more evident later when her storytelling becomes increasingly incoherent. Note the pauses and incomplete utterances and repeated references to her inability (to cope perhaps) (lines 17-18). Trauma storytelling, by definition, is broken and disconnected, not so much because the teller is searching for the right words but because a vocabulary that adequately captures this immensely emotional experience is not available. Thus, we find what Brockmeier (2008:29) calls 'black outs' or 'voids in the narrative flow', which signify a rupture within the victim's existence. Note that she says three times 'I cannot' (lines 17-18) and the reference to being sick even suggests physical pain.

In a situation where trauma unfolds and the victim is re-experiencing painful events and crying about them, it is possible that switching to an emotionally more neutral code might help the teller create some kind of emotional distance. A final note should be made about the fieldworker's language. Something happens to his intonation in line 10 ("how do you feel now?") and even more so in line 13 ("just take your time, right?") and line 19 ("it's okay"). Hepburn \& Potter (2007:94) call it a 'hearably sympathetic intonation'. It is an empathetic response that has similarities with child-directed speech: there is slowed speech, more pronounced intonation patterns, and repetition (line 10). The function of this 
register is to communicate empathy and encourage the teller to continue her story. Within social constructionism, selves are discursively constructed, so Sari's identity as 'a crying person' should not be separated from other group members' feedback, which essentially provides her with a licence to cry.

The next example is also from Sari's narrative and it shows how repeated switching back and forth between Bahasa and English occurs. After FW's comment “it's okay" (line 19 in (1)), Sari switches back and continues her story in Bahasa for about four minutes. She mentions that her employers hurt her, and then the fieldworker asks the question in line 1.

1 FW: how did they, how did they hurt you? (2.0)

2 Sari: uhm?

3 FW: how did they hurt you?

4 Sari: ya gitu, maksudnya suka ngadu-ngadu gitu yang enggak-enggak,

5 bilang yang enggak-enggak gitu, orang dia yang pacaran udah lama,

6 orang dia yang bermesraan, orang saya kayak obat nyamuk disitu,

7 malah saya yang dituduh, saya diem aja, diem, ya Allah (cries quietly)

8 kebenaran entah sekarang, entah berapa tahun (cries quietly) 'yeah like, [she is] a snitch, reporting lies, reporting lies like that, she's the one who's dating for a long time, she's the one who's cuddling, I'm like mosquito repellent there, instead I was being accused, I just kept quiet, quiet, oh my God (cries quietly) the truth either now or later [will come out] (cries quietly)'

(Nine turns left out during which the translator asks for clarification)

9 Sari: sampe saya minta obat kalo saya sakit kepala, apu gitu,

10 ga pernah ngasih, bajupun saya beli sendiri, apa-apa, sabun

11 semuanya beli sendiri

'I asked for medicine if I have a headache, or [something] like that they never give [me], even clothes I bought it myself, everything, soap, bought everything myself'

12 Int: uhm, the story that came up is about the employer never

13 //providing// (quietly to FW)

14 Sari: //believe me// they never believe me, whatever I say they

15 never believe me, she believe the other maid (sobs)

16 FW: okay

17 Sari: so what I have to do, I'm just silent silent, I keep (sobs)

18 FW yeah

The continuation of Sari's story also has characteristics of a trauma narrative. It is somewhat incoherent: in line 7 ("I just kept quiet"), it is not clear what she did not say anything about (possibly her female employer's affair). It is also not clear how the comment in lines 9-11 ("I asked for medicine... everything myself") fits into the rest of the story, and in line 17 , we have another example of incoherent storytelling 
with voids in the narrative flow. Yet another characteristic feature of trauma storytelling is that the teller seems so engulfed in her story that she ignores questions from her audience (Ladegaard 2015). She does not seem to hear the fieldworker's question in line 1 (notice the lengthy pause followed by a request for the question to be repeated), and when she responds, she switches to Bahasa, which would constitute a case of linguistic divergence, which is rare in social interaction and normally seen as uncooperative behaviour (Gallois, Ogay, \& Giles 2005). Sari is not trying to be uncooperative, but she is more likely so engulfed in her story that it takes over and tells itself as it were. The same applies to the translator's attempt to explain what Sari has been saying, which is interrupted mid-sentence (line 13).

Prior to line 1, the storytelling is in English; then Sari switches to Bahasa (line 4) in response to a question in English, and, in line 14, she switches back to English. It is noticeable again that lines 14-15 and line 17 constitute a climax in the storytelling. Sari is visibly and audibly distraught. Throughout her narrative, she keeps coming back to the false accusations and to the fact that nobody believed her innocence (lines 14-15). This no doubt constitutes an unfinished event, which requires more talking (and more crying). Labott (2001) argues that in psychotherapy clients reawaken traumatic memories and their accompanying affect. What happens through storytelling is that individuals try to come to terms with their loss or grief and through repeated crying, gradually come to accept it. Being falsely accused of wrongdoing and being betrayed by a fellow DMW are at the core of Sari's trauma, so when she recounts this immensely painful experience, she again switches to English, possibly to create some form of distance from the immediacy of the event, or to appeal for empathy from the fieldworker (i.e. addressee specification, Gumperz 1982). Her response at the time when this happened to her was silence, which is stressed by repeating the key word (line 17), and she now has to move from passivity to resistance in order to come to terms with her trauma.

This painful process is underlined in the last example from Sari's narrative, a short excerpt that occurred towards the end of her story.

1 Int: $\quad \mathbf{x x x}$ ada ga saudara atau siapapun yang mbak bisa percaya?

'xxx do you have relatives or somebody that you can trust?'

2 Sari: ya sudah saya coba, tapi ya kan gimana, kurang kan kadang, gitu 'yeah I have tried, but yeah how, [I] lack sometimes, like that'

3 Sari: every time I try (sobs) it comes back again and again and again

$4 \quad$ and again (sobs)

5 FW: yeah, yeah

In (1) and (2), the CS is inter-sentential (Poplack 1980); in (3), it is intra-sentential and follows a rather incoherent reply that makes little sense (line 2). Li Wei (1997) argues that intra-sentential CS is often accompanied by a pause, hesitation, or repetition before delivery to signify the change. This is not the case in Sari's story, 
which suggests that the switch is not 'premeditated' and therefore arguably more emotionally charged. The first part of the turn (line 2) is in Bahasa and she switches to English abruptly in line 3 to make a very emotional statement: that no matter how hard she tries, the traumatic experiences keep haunting her. Note how she repeats 'again' four times to stress the gravity of her problem (lines 3-4). Again, her statement, uttered in English, is accompanied by sobbing, and we could argue that the switch might allow her to talk about her emotions without being consumed by them.

The next example is from a sharing session in Central Java with six returnees. Excerpt (4) is from the beginning of the sharing where the women discuss what it was like for them to be migrant workers. All of them have horrifying stories to tell, and Harum has just told the group in Bahasa how she was accused of stealing a necklace, kicked out of the house, and handed over to the police. Then the interpreter asks if she received any compensation.

(4) Harum, forty-four years old, two years in Singapore, two years in Malaysia, six years in Taiwan

\begin{tabular}{|c|c|c|}
\hline 1 & Int: & $\begin{array}{l}\text { dapet ga yang permintaannya mbak? } \\
\text { 'did you get your request [compensation]?' }\end{array}$ \\
\hline 2 & Harum: & iya ('yes') but only, did not get one month's salary and ticket \\
\hline 4 & FW: & $\begin{array}{l}\text { very common story unfortunately, yeah, sorry to hear } \\
\text { that, yeah }\end{array}$ \\
\hline 5 & Harum: & $\begin{array}{l}\text { that's mhm: I'm working to take care of the baby, } \\
\text { cleaning the house is }(1.0) \text { must be very very clean }\end{array}$ \\
\hline 7 & FW: & $\mathrm{mhm}$ \\
\hline $\begin{array}{l}8 \\
9\end{array}$ & Harum: & $\begin{array}{l}\text { eh: twelve o'clock midnight, still washing cars in the } \\
\text { car park (1.0) I'm sleeping sometimes } 1 \text { o'clock }\end{array}$ \\
\hline 10 & & 2 o'clock and I wake up 5:30 \\
\hline 11 & FW: & $\mathrm{mhm}$ \\
\hline 12 & Harum: & $\begin{array}{l}\text { and then, [they do] not give me enough food like that, } \\
\text { so I'm always hungry there (sobs) }\end{array}$ \\
\hline 14 & FW: & yeah, yeah \\
\hline
\end{tabular}

The intra-sentential switch from Bahasa to English (line 2) could be caused by the fact that 'one month's notice and return ticket' is a standard phrase that is part of migrant-worker register. Thus, the switch can be seen as lexical borrowing, which makes sense because the English term would be unmarked in the context (MyersScotton 1993). If a DMW's contract is terminated prematurely, she is supposed to get whatever salary she is owed plus an additional month's salary and return airfare. But in many cases, she gets nothing, or only part of the compensation (line 3). The fieldworker's comment is also an expression of sympathy, and this may be one reason that Harum continues her story in English. So far, her story has been in Bahasa; it is a story of blatant abuse and exploitation and eventually, a false accusation of stealing a necklace that leads to termination of contract and arrest. She has 
had little feedback from the interpreter or other group members, and she has told her story without display of much emotion. But the fieldworker's expression of empathy ("sorry to hear that, yeah", lines 3-4) does something to her; she becomes audibly more emotional as she continues her story and eventually breaks down and sobs in line 13 as she recollects the long hours she worked, the fatigue, and the hunger.

Harum's narrative echoes many of the stories that were recorded at the church shelter (Ladegaard 2017). When a DMW arrived at the shelter after months of excessive labour, no rest, too little sleep and food, she would often find it immensely difficult to narrate the experience. The problem is what Brockmeier (2008:29) calls 'the traumatic gap' between talk and what the talking is about: 'An experience that goes beyond all common and ordinary modes of experience, a break not just with a particular form of representation but with the very possibility of representation at all'. DMWs are often struggling to tell their stories because there is no adequate representation. In his account of life in Auschwitz, Primo Levi explains how the prisoners' experiences cannot be encompassed by ordinary language (Langer 1980). Their hunger, he explains, is not the hunger of missing a meal, but, as DMWs testified in countless sharing sessions at the shelter, it is the constant hunger of living off food scraps and never having a decent meal.

The emotional intensity with which Harum tells her story in a trembling voice suggests that this may also have been her experience. The desire for empathy may have been what prompted her to continue her story in English. Empathy DOES something to the teller (Shuman 2005). It reassures her that this is a safe environment for narrating painful self-disclosures; it connects the storyteller and her audience and makes the story a shared experience (Medved \& Brockmeier 2008). However, as we saw in the previous examples, it is also possible that Harum is able to distance herself more from these gruelling experiences if she narrates this difficult passage in English (Tehrani \& Vaughan 2009).

The next story is from the beginning of the same sharing session. Mawar is the first to share, and she begins her narrative in Bahasa. Then the sharing is interrupted by a newcomer, and after she has settled down, the interpreter speaks to Mawar (line 1).

(5) Mawar, thirty-four years old, two and a half years in Singapore, two years in Kuwait, one year in Hong Kong

1 Int: oke, mungkin bisa mulai dari mbak, dari ceritanya mbak tadi,

2 di tadi kan di Hong Kong xxx ada apa ceritanya disana 'okay, perhaps you can start from you, from your previous [story], earlier in Hong Kong xxx what happened there?'

3 Mawar: uhm: I want to tell you first, when I'm in Singapore

4 I'm a success because I have a good employer

5 FW: okay 


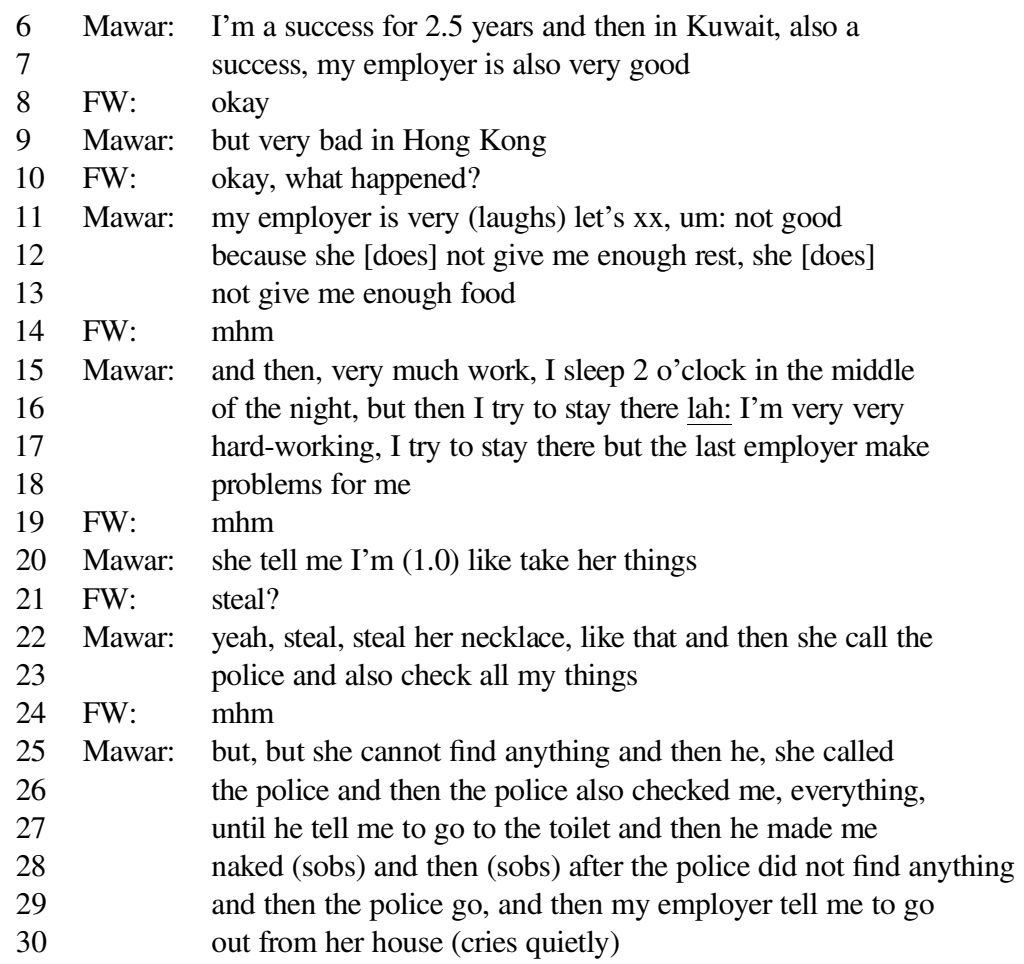

Having started her narrative in Bahasa, and after a brief interruption during which another friend joins the group, Mawar chooses to continue in English, despite the interpreter addressing her in Bahasa (lines 1-2). Like we saw in (2), this constitutes an example of linguistic divergence, which is marked in normal conversation and often signifies that the speaker, for some reason, wants to challenge contextual norms or speaker roles (Ladegaard 2009). However, Mawar is not trying to challenge her interlocutor, so the switch to English in line 3 is probably caused by other factors.

The first part of Mawar's story is not particularly difficult to tell. It is the positive part of her narrative in which she emphasises that she was a success in Singapore and Kuwait because she had good employers (lines 4, 7). The positive introduction suggests that she knows where the story is headed. After she has finished her narrative she says (in subsequent lines not reported here): "this is my sad self-story", so she is aware that the journey of her narrative self is a sad one. In line 9 , she moves to the difficult part of her story, which we can both see and hear. Her voice becomes wobbly and she appears less confident. The laughter (line 11) is not humorous, but more likely nervous laughter used to conceal embarrassment (Partington 2006). Sadly, Mawar's story about her life as a DMW in Hong Kong is not unique. In fact, it is the norm for the more than 1,000 women seeking help at church shelters every year: working days of sixteen hours or more and having very little food and 
sleep (lines 12-15) (Ladegaard 2017). And if the relationship turns sour and the employer wants to terminate the contract prematurely without paying the compensation, she accuses her of theft, which allows her to dismiss the helper immediately.

There is an example of lexical borrowing in line 16. Mawar uses the Cantonese sentence-final particle lah, which is commonly found in DMWs' narratives but with different semantic implications. In Cantonese, lah [啦] signifies the end of a turn, but when used by DMWs, the semantics has shifted: it is used for emphasis, meaning 'really?', 'right', or 'okay'. The climax in Mawar's storytelling comes in lines 25-30, and it might be in anticipation of this extremely difficult part of the story that she switches to English in line 3 to somehow ease the storytelling. The police officer takes her to the bathroom and demands that she take off all her clothes. She sobs when she gets to this part of the story, and she never explains what happened after she was ordered to strip naked. She only says 'and then', and sobs for a few seconds. It is likely that she was sexually assaulted, but we do not know. However, the sobbing in combination with an incomplete adverbial phrase used to signify a sequence of events suggests that something happened which she is unable to tell (Ladegaard 2014).

Recalling this traumatic experience does something to Mawar: from being a confident speaker who masters both Bahasa and English and who has eye contact with her audience, she is in tears when she completes her story, and (as stated in the fieldnotes), she looks at her hands, which are tightly squeezing her handkerchief. What happens in Mawar's narrative is a 'reawaken[ing] of traumatic memories... along with their accompanying affect' (Labott 2001:214), and however painful it is, narrative therapy argues that this is what trauma victims must do. As Brison (1999:48) claims, 'SAYING something about trauma DOES something to it': through the telling and retelling of trauma narratives, dominant repressive discourses are questioned, and this may be the first step for the victim to move from victimhood to survival and beyond (Duvall \& Béres 2007).

The last example is from a sharing session in Central Java with Yulia, a mother of two who has worked twelve years in Hong Kong. When she got pregnant (by her Indonesian husband), she let her employer understand (in very subtle ways) that she knew about her rights and would sue the family if they fired her. Therefore, the employer agreed to let her have one year of unpaid leave and go back to Indonesia with her baby, and then return to Hong Kong to work for the family. Yulia's story is different from many of the other stories in the data: her baby is 'legitimate' and therefore accepted by the family, and she is going back to work for a reasonably good employer in Hong Kong.

(6) Yulia, thirty-eight years old, twelve years in Hong Kong

1 Int: apakah anda menerima bantuan keuangan dari pihak lain?

'did you receive any financial assistance from anyone?' 


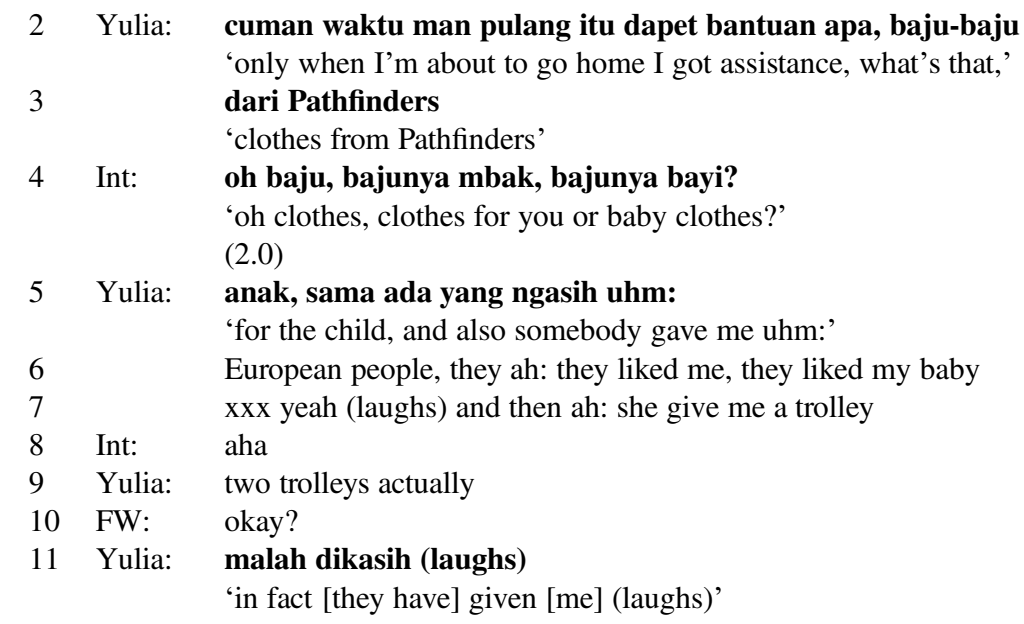

The sharing session with Yulia was the first one we did on the fieldtrip to Java. This is important because the interpreter is not yet sure what her role should be. The assignment given to her was to let the women speak as freely as possible and only ask clarifying questions if required. The question in line 4 seems redundant, given that the women were supposed to talk about the three general questions stated earlier. Whether Yulia received clothes for herself or for the baby is irrelevant, and it is not clear why the interpreter asked the question. If we take a closer look at the discourse, Yulia's response indicates that she is also surprised. First, the two-second pause (line 4) suggests that she is unsure how to respond. Second, there is a prolonged hesitation marker ("uhm:", line 5) followed by an intrasentential switch from Bahasa to English (line 6)

Speech accommodation is arguably not the issue here. If she were converging to the English-speaking fieldworker, she probably would have kept the conversation in English, but in response to his comment, "okay?" (line 10), with sharply rising intonation suggesting a question, she performs another intra-sentential switch back to Bahasa (line 11). What may explain this case of CS is embarrassment. Asking a person if she has received any charity is a face-threatening activity (FTA), especially for a proud woman like Yulia who takes pride in her ability to support her family. It may therefore be perceived as a slap in the face when the interpreter asks if she received any charity while she worked in Hong Kong. And Yulia's response also indicates embarrassment: there are two prolonged hesitation markers ("ah:", lines 6,7), and two examples of what may be seen as nervous laughter (lines 7, 11). Bond \& Lai (1986) found that reduction of embarrassment was a significant reason for bilingual speakers to switch to the less emotionally charged code, and it is possible that Yulia's shift to English allows her to talk about an embarrassing topic without loss of face.

Another possible reason for Yulia's switch to English in line 6 is linguistic divergence. In a situation of asymmetric power relationship, it is likely that the 
socially inferior person may adopt a different speech pattern to that of her interlocutor to signal that she wants to dissociate herself from the speaker. Central to the idea of speech accommodation is that 'communication is not only a matter of exchanging referential information, but that interpersonal as well as intergroup relationships are managed by means of communication' (Gallois et al. 2005:123). Thus, 'the strategy of [speech] divergence leads to an accentuation of differences between self and other' (Gallois et al. 2005:123). In a situation where a socially inferior person has been embarrassed by another ingroup member, but because of the power imbalance, is left with few options when it comes to rebutting the FTA, linguistic divergence gives her the possibility to protest in subtle indirect ways, which would not allow the interlocutor to label her as rude (Ladegaard 2009). Finally, Yulia's switch could also be seen as an example of metaphorical switching motivated by the change of topic (European people, line 6) (Gumperz 1982).

\section{I S C U S S I N A N D C O N C L U S I O N}

As previously mentioned, our knowledge about the relationship between language and emotion is based overwhelmingly on data from questionnaires, interviews, and laboratory studies. With a few exceptions (e.g. Marcos 1976a,b; Bond \& Lai 1986; Tehrani \& Vaughan 2009; Ferreira 2017), research on emotion and CS has focused on self-reports, perception, and recollection of experience rather than actual linguistic behaviour, and the studies that look at actual language rarely focus on an analysis of discourse. Even studies that explore the use of CS and emotion in counselling are often based on simulated counselling sessions with students (e.g. Ramos-Sanchez 2007), or on interviews with health professionals (e.g. Santiago-Rivera, Altarriba, Poll, Gonzales-Miller, \& Gragun 2009). This means that questions about how and under what circumstances CS is used, and its relationship with emotion in the discourse context, go largely unanswered. It is to this area of enquiry that this article attempts to make a contribution.

Based on questionnaire feedback from more than 1,500 multilinguals, Dewaele (2010) concludes that for a minority of the participants, the L1 had ceased to be the dominant language. For these people, it was also no longer the preferred language of emotional expression. While the early research on bilingualism and emotion indicated that for most bilinguals, L1 was the preferred language to communicate emotions in, and L2 (or LX) the preferred language of emotional detachment, recent research argues that the picture is more complex (Pavlenko 2004). Multilingual existence is multifaceted, and what happens is that 'additional language socialisation may change speakers' perceptions of language emotionality and allow them to invent new emotional personae' (Pavlenko 2004:201). Dewaele (2010) argues along the same lines and concludes that the emotional prevalence of multilingual speakers' L1 is not a law of nature but is more likely to reflect the fact that multilinguals often remain dominant in their L1. Thus, the more frequently the LX is 
used, the more likely it is that it will be used for both emotional and nonemotional purposes.

Dewaele (2010) concludes that his participants claim they use CS to avoid upsetting their interlocutors. They can pick words from within their linguistic repertoires with more or less emotional content to suit their needs. Multilinguals use CS strategically to develop personalised emotion scripts, usually shared by their family or peers. However, there was also a consistent finding that CS was reportedly used more frequently when the discussion topics were of an emotional nature and when the interlocutor was familiar, as opposed to nonemotional topics being discussed with strangers. Therefore, Dewaele (2010) concludes that while there is no clear justification for claiming that L1 is more emotional than LX, there is evidence to suggest a link between language and emotion so that for bilinguals, shifting language allows speakers to express certain emotions more clearly, or avoid topics or words that have negative associations in one of the speaker's languages.

No matter what design we apply to our research, it will never be complete because the issues we are studying in the humanities and social sciences are always more complex than what can be captured by a single research design (Dewaele 2010). Therefore, one study can provide only a glimpse of a multifaceted reality, and to get a more complete picture, we need to look more holistically at research findings. The research in this article adds an under-researched dimension to the study of language and emotionality by drawing on analyses of CS in discourse. The narratives were not collected with the aim of analysing CS and emotion, but the data arose out of conversations about DMWs' experiences. Thus, we can be fairly confident there was no experimenter bias, or attempts to provide evidence in support of a particular hypothesis.

If we compare the discourse data from this study with the mostly quantitative findings reported in the literature, there is some evidence in the current study to support the assumption in early research that bilingual speakers may switch to a L2 to create some form of emotional distance. The data demonstrate that speakers tend to switch from their L1 (Bahasa) to their L2 (English) when they are narrating particularly difficult, emotionally charged experiences. The evidence that recalling these memories is associated with high emotionality is consistent with intensive crying (sobbing) during or after the telling. Thus, switching to a less emotionally charged code might make the experience more tellable (Shuman 2005). By contrast, we could also argue that the intensive crying shows that the speaker is still overwhelmed by emotion, despite the switch to English. Either way, we can conclude that language and emotionality are interrelated, given that narrators consistently switch language at particularly difficult junctions in the narratives as evidenced by intense crying (excerpts (1)-(4)), or in anticipation of a painful memory (excerpt (5)). Excerpt (6) is different in that it deals with embarrassment more than emotional devastation.

Another issue, which is relevant for this article but not widely addressed in the literature, is the complexity of the encoding process for bi- or multilinguals. It has 
been suggested that recalling an (emotional) experience in L1 increases the levels of emotional texture and complexity compared to recalling the events in L2 (Schrauf 2000). However, Tehrani \& Vaughan (2009) argue that for a balanced bilingual, the most significant factor for increasing the quality of the emotional content of the experience is the language and context in which the incident was encoded. The case they examine is a French-English bilingual teacher who was subjected to extreme workplace bullying while teaching in France. In the counselling sessions, it turned out that the use of English was unhelpful when it came to recalling the emotional impact the bullying had on the victim. Because the incident happened in French, the emotional impact of the traumatic experience was lost in translation as it were. However, it also transpired during therapy that the dilution of the emotional response to the incident, which was brought about by using English, was helpful because it assisted the victim to retrieve the traumatic memory without triggering the negative emotional response. The use of English brought about feelings of psychological detachment, and the victim discovered that "by working in English she could activate her English self to heal her French persona' (Tehrani \& Vaughan 2009:14).

We do not know which language was used during the traumatic events experienced by the DMWs in this study, but it was most likely English. DMWs do not usually speak Arabic, and in Hong Kong, the lingua franca was almost certainly English. So the women probably experienced being traumatised in what for them was an English-speaking context, and therefore, following Tehrani \& Vaughan's (2009) argumentation, would experience the strongest emotional response when the experience was narrated in English. This would be supported by the intense forms of crying in excerpts (1)-(5). However, it is also possible that the use of English would bring about feelings of psychological detachment, which would allow the person to narrate the event without being consumed by negative emotions. And while the women are perfectly proficient in English and might qualify as late bilinguals, they are not equally fluent in both languages. This means their use of English is probably more instrumental and possibly more detached from their emotional life.

There is no conclusive evidence in this article that $\mathrm{L} 1$ behaviour is more emotional, or $\mathrm{L} 2$ behaviour is preferred for emotional detachment. But there is evidence to show that CS is used for emotional alignment. The increased emotionality and anxiety involved in recalling traumatic memory manifests itself linguistically in a change of code. Whether the change to L2 facilitates the recall and makes the accompanying emotional response more impactful because this was the language in which the experience was encoded, we do not know. The intense crying suggests that it might. If this is the case, the switch to L2 might also be part of a healing process, which enables the victim to re-experience the most threatening aspects of the trauma, and by responding to them emotionally through crying, alleviate (some of) the trauma-related anxiety (Foa, Molnar, \& Casham 1995). Another possible reason for the CS is that the women are accommodating to the 
English-speaking fieldworker to establish connection and appeal for sympathy (Myers Scotton 1976).

Even though some scholars have concluded that research on language and emotionality is inherently indeterminate, this should not deter us from further study (Harris et al. 2006). Based on all of the examples of CS in this study (not just the ones included in this article), it is safe to conclude that language use is emotionally charged and switching code DOES something to the speaker emotionally (hence the intense crying). This is supported by research on skin-conductance response, which measures the body's physical response to stress and anxiety (Harris et al. 2006). At a general level, this finding also aligns with Myers-Scotton's (1993) claim that CS creates contrast in the conversation; the switch to English in a predominantly Bahasa-speaking context can be characterised as a marked choice that would inevitably put more focus on the more emotional parts of the conversation. Or, as Gardner-Chloros (2009:69) argues, CS can be 'exploratory' in that it helps speakers feel their way to the most advantageous outcome, be this creating emotional distance, and/or accommodation and appeal for sympathy.

However, an arguably more important question that this article has not addressed is the human tragedies behind these stories. The tellability of trauma narratives is compromised by the unacceptability of the events (Shuman 2005), and the fact that these atrocities DID happen to innocent women-whose one desire was to be able to provide for their family - constitutes a challenge. First, it encourages us as scholars to, whenever possible, translate our research into social action. We need to work not just on socially marginalised groups and use the data they provide us with for our own purposes; we need to work FOR and WITH them (Cameron, Fraser, Harvey, Rampton, \& Richardson 1992) and use what we know about their lives to address larger issues of social injustice, exploitation, and human trafficking.

Second, we need to accept that the stories these women tell will always be unsettling. They are often incoherent, with voids in the narrative flow, and they therefore violate listeners' expectations. People generally do not want to hear stories of human-inflicted trauma and, as Harvey, Mishler, Konen, \& Harney (2000:294) argue, 'if they cannot avoid listening, then they prefer coherent stories, ones that make sense by following a culturally-preferred plot from a state of suffering and pain to one of wholeness and recovery'. However, these are not the stories told by DMW returnees in Java. It is important that we learn to HEAR what our participants have to say, and if we do that, we might be hopeful that we have helped them move just one small step forward in their long and painful journey towards recovery. As Harvey and colleagues (2000:308) conclude: 'If we can listen to them and support their own efforts toward meaning, they may be better able to move through the process of restorying and on to new post-survivor identities'. 


\section{A P P E N D IX: TR A N S C R IP TION C ONVENTIONS}

\begin{tabular}{|c|c|}
\hline bold & Bahasa \\
\hline$\underline{\text { underline }}$ & Cantonese \\
\hline [it's a] & word(s) inserted by the transcriber to ease comprehension \\
\hline$(2.0)$ & $\begin{array}{l}\text { Short pause, less than } 0.5 \text { second } \\
\text { pause in seconds }\end{array}$ \\
\hline : & prolonged vowel sound (as in ah:) \\
\hline $\mathrm{xx}$ & incomprehensible \\
\hline // & interruption \\
\hline //as I said// & overlapping speech \\
\hline$?$ & question/rising intonation \\
\hline
\end{tabular}

\section{N O T E S}

*The research reported in this article was supported by a competitive research grant from the University Grants Committee of Hong Kong (grant number: PolyU 2444/13H). I am grateful for their support, and for the support of staff and volunteers at Pathfinders, a migrant worker NGO who works tirelessly to support migrant women. Special thanks to Kristina Zebua, Salas and Aan, and Mock Cholily who organised my fieldtrip in Indonesia. Last but not least, my immense gratitude goes to all the migrant women who shared their stories with me.

${ }^{1}$ Transcription conventions are given in the appendix.

\section{R E F E R E N C E S}

Augoustinos, Martha; Ian Walker; \& Ngaire Donaghue (2014). Social cognition: An integrated introduction. 3rd edn. London: SAGE.

Bond, Michael Harris, \& Tat-ming Lai (1986). Embarrassment and code-switching into a second language. The Journal of Social Psychology 126(2):170-86.

Brison, Susan J. (1999). Trauma narratives and the remaking of the self. In Mieke Bal, Jonathan Crewe, \& Leo Spitzer (eds.), Acts of memory: Cultural recall in the present, 39-54. Hanover, NH: Dartmouth College Press.

Brockmeier, Jens (2008). Language, experience, and the 'traumatic gap': How to talk about 9/11? In Lars C. Hydén \& Jens Brockmeier (eds.), Health, illness and culture: Broken narratives, 16-35. New York: Routledge.

Burr, Vivien (2015). Social constructionism. 3rd edn. London: Routledge.

Cameron, Deborah; Elizabeth Fraser; Penelope Harvey; Ben Rampton; \& Kay Richardson (1992). Researching language: Issues of power and method. London: Routledge.

Dewaele, Jean-Marc (2010). Emotions in multiple languages. Basingstoke: Palgrave Macmillan. (2016). Multi-competence and emotion. In Vivian Cook \& Li Wei (eds.), The Cambridge handbook of linguistic multi-competence, 461-77. Cambridge: Cambridge University Press.

Duvall, Jim, \& Laura Béres (2007). Movement of identities: A map for therapeutic conversations about trauma. In Catrina Brown \& Tod Augusta-Scott (eds.) (2007), 229-50. Narrative therapy: Making meaning, making lives. Thousand Oaks, CA: Sage.

Ferreira, A. Virginia Acuña (2017). Code-switching and emotions display in Spanish/Galician bilingual conversation. Text \& Talk 37(1):47-69. 


\section{CODESWITCHING AND EMOTIONAL ALIGNMENT}

Foa, Edna B.; Chris Molnar; \& Laurie Cashman (1995). Change in rape narratives during exposure therapy for posttraumatic stress disorder. Journal of Traumatic Stress 8(4):675-90.

Gallois, Cindy; Tania Ogay; \& Howard Giles (2005). Communication accommodation theory: A look back and a look ahead. In William Gudykunst (ed.), Theorizing about intercultural communication, 121-48. Thousand Oaks, CA: SAGE.

Gardner-Chloros, Penelope (2009). Code-switching. Cambridge: Cambridge University Press.

Gumperz, John (1982). Discourse strategies. Cambridge: Cambridge University Press.

Harris, Catherine L.; Jean Berko Gleason; \& Ayse Aycicegi (2006). When is first language more emotional? Psychological evidence from bilingual speakers. In Aneta Pavlenko (ed.) (2006). Bilingual minds: Emotional experience, expression and representation, 257-83. Clevedon: Multilingual Matters.

Harvey, Mary R.; Elliot G. Mishler; Karestan Konen; \& Patricia A. Harney (2000). In the aftermath of sexual abuse: Making and remaking meaning in narratives of trauma and recovery. Narrative Inquiry 10(2):291-311.

Hepburn, Alexa, \& Jonathan Potter (2007). Crying receipts: Time, empathy and institutional practice. Research on Language and Social Interaction 40:89-116.

Hoffman, Eva (1989). Lost in translation: A life in a new language. London: Vintage.

Javier, Rafael A. (2007). The bilingual mind: Thinking, feeling and speaking in two languages. New York: Springer.

Koven, Michéle (2006). Feeling in two languages: A comparative analysis of a bilingual's affective displays in French and Portuguese. In Aneta Pavlenko (ed.), 213-26. Bilingual minds: Emotional experience, expression and representation. Clevedon: Multilingual Matters.

Labott, Susan M. (2001). Crying in psychotherapy. In Ad J. J. M. Vingerhoets \& Randolph R. Corneluis (eds.), Adult crying: A biopsychosocial approach, 69-89. Hove: Brunner-Routledge.

Ladegaard, Hans J. (2009). Pragmatic cooperation revisited: Resistance and non-cooperation as a discursive strategy in asymmetrical discourses. Journal of Pragmatics 41:649-66.

(2014). Crying as communication in domestic helper narratives: Towards a social psychology of crying in discourse. Journal of Language and Social Psychology 33:579-605.

(2015). Coping with trauma in domestic migrant worker narratives: Linguistic, emotional and psychological perspectives. Journal of Sociolinguistics 19(2):189-221.

(2017). The discourse of powerlessness and repression: Life stories of domestic migrant workers in Hong Kong. London: Routledge.

Langer, Laurence L. (1980). The dilemma of choice in the deathcamps. Centerpoint 4:222-31.

Li Wei (1997). Banana split? Variations in language choice and code-switching patterns in two groups of British-born Chinese in Tyneside. In Rodolfo Jacobson (ed.), Codeswitching worldwide, 153-75. Berlin: Mouton de Gruyter.

Marcos, Luis R. (1976a). Linguistic dimensions of the bilingual patient. The American Journal of Psychoanalysis 36(4):347-54.

(1976b). Bilinguals in psychotherapy: Language as an emotional barrier. American Journal of Psychotherapy 30(4):552-60.

Martinovic, Ines, \& Jeanette Altarriba (2013). Bilingualism and emotion: Implications for mental health. In Tej K. Bhatia \& William C. Ritchie (eds.), The handbook of bilingualism and multilingualism, 2nd edn., 292-320. Oxford: Wiley-Blackwell.

Medved, Maria, \& Jens Brockmeier (2008). Talking about the unthinkable: Neurotrauma and the 'catastrophic' reaction. In Lars C. Hydén \& Jens Brockmeier (eds.), Health, illness and culture: Broken narratives, 54-72. New York: Routledge.

Myers Scotton, Carol (1976). Strategies of neutrality: Language choice in uncertain situations. Language 52(4):919-41.

(1993). Social motivations for code-switching: Evidence from Africa. Oxford: Oxford University Press. 
Necef, Mehmet (1999). The transformation of the culture and language of intimacy. Psyke \& Logos 3:435-55.

Ochs, Elinor, \& Lisa Capps (2001). Living narratives: Creating lives in everyday storytelling. Cambridge, MA: Harvard University Press.

Panayiotou, Alexia (2004). Switching codes, switching code: Bilinguals' emotional responses in English and Greek. Journal of Multilingual and Multicultural Development 25(3):124-39.

Parreñas, Rachel S. (2005). Children of global migration: Transnational families and gendered woes. Stanford, CA: Stanford University Press.

Partington, Alan (2006). The linguistics of laughter: A corpus-assisted study of laughter-talk. New York: Routledge.

Pavlenko, Aneta (2004). 'Stop doing that, la komu skazala!': Language choice and emotions in parentchild communication. Journal of Multilingual and Multicultural Development 25(3):179-203.

(2005). Emotions and multilingualism. Cambridge: Cambridge University Press.

Poplack, Shana (1980). 'Sometimes I'll start a sentence in Spanish y termino en Español': Toward a typology of code-switching. In Jon Amastae \& L. Elias-Olivares (eds.), Spanish in the United States: Sociolinguistic aspects, 230-63. Cambridge: Cambridge University Press.

Ramos-Sanchez, Lucila (2007). Language switching and Mexican-Americans' emotional expression. Journal of Multicultural Counseling and Development 35:154-66.

Santiago-Rivera, Azara L.; Jeanette Altarriba; Norma Poll; Normaris Gonzales-Miller; \& Carrie Gragun (2009). Therapists' views on working with bilingual Spanish-English clients: A qualitative investigation. Professional Psychology: Research and Practice 40(5):436-43.

Saville-Troike, Muriel (2003). The ethnography of communication. 3rd edn. Oxford: Blackwell.

Schrauf, Robert W. (2000). Bilingual autobiographical memory: Experimental studies and clinical cases. Culture and Psychology 6(4):387-417.

Shuman, Amy (2005). Other people's stories: Entitlement claims and the critique of empathy. Urbana: University of Illinois Press.

Tehrani, Noreen, \& Sarah Vaughan (2009). Lost in translation: Using bilingual differences to increase emotional mastery following bullying. Counselling and Psychotherapy Research 9(1):11-17.

Thass-Thienemann, Theodore (1973). The interpretation of language, vol. I: Understanding the symbolic meaning of language. New York: Jason Aronson.

Toolan, Michael (2001). Narrative: A critical linguistic introduction. 2nd edn. London: Routledge.

Vingerhoets, Ad J. J. M.; A. Jan W. Boelhouwer; Miranda A. L. van Tilburg; \& Guus L. van Heck (2001). The situational and emotional context of adult crying. In Ad J. J. M. Vingerhoets \& Randolph R. Cornelius (eds.), Adult crying: A biopsychosocial approach, 69-89. Hove: Brunner-Routledge.

White, Michael, \& David Epston (1990). Narrative means to therapeutic ends. New York: Norton.

Wierzbicka, Anna (1997). Understanding cultures through their key words. New York: Oxford University Press.

(Received 21 August 2017; revision received 22 March 2018; accepted 4 May 2018; final revision received 14 May 2018)

Address for correspondence: Department of English

The Hong Kong Polytechnic University Hung Hom, Kowloon Hong Kong hans.ladegaard@polyu.edu.hk 